\title{
Chemokine mRNA expression in gastric mucosa is associated with Helicobacter pylori cagA positivity and severity of gastritis
}

\author{
T Shimoyama, S M Everett, M F Dixon, A T R Axon, J E Crabtree
}

Molecular Medicine Unit, St James's

University Hospital, Leeds, UK

J E Crabtree

Centre for Digestive Disease, Leeds General Infirmary, Leeds, UK $S M$ Everett

M F Dixon

A T R Axon

First Department of Internal Medicine, Hirosaki University School of Medicine, Hirosaki, Japan

T Shimoyama

Correspondence to: Dr J E Crabtree, Division of Medicine, Level 7, Clinical Sciences Building, St. James's University Hospital, Leeds LS9 7TF, UK.

Accepted for publication 13 May 1998

\begin{abstract}
Aim-To investigate the association between the quantity of gastric chemokine mRNA expression, severity of gastritis, and cagA positivity in Helicobacter pylori associated gastritis.

Methods-In 83 dyspeptic patients, antral and corpus biopsies were taken for semiquantitative reverse transcription polymerase chain reaction (RT-PCR) and histological grading of gastritis. Gastritis was evaluated by visual analogue scales. Quantities of chemokine (IL-8, GRO $\alpha$, ENA-78, RANTES, MCP-1) RT-PCR products were compared with G3PDH products. Each sample was also evaluated for the presence of cagA and ureA mRNA by RT-PCR.

Results-mRNA expression of all five chemokines was significantly greater in $H$ pylori positive than in $H$ pylori negative mucosa. In $H$ pylori positive patients, in the antrum C-X-C chemokine mRNA expression was significantly greater in cagA positive patients than in cagA negative patients, but there were no significant differences in $\mathrm{C}-\mathrm{C}$ chemokine mRNA expression. In $H$ pylori positive patients, chemokine mRNA expression in the corpus was less than in the antrum. In contrast to the antrum, only GRO $\alpha$ mRNA expression was significantly greater in cagA positive infection. Polymorphonuclear cell infiltration was correlated with C-X-C chemokine mRNA expression. Significant correlations were also found between bacterial density and C-X-C chemokine mRNA expression.

Conclusions-In H pylori infection, C-X-C chemokines may play a primary role in active gastritis. Infection with cagA positive $H$ pylori induces greater gastric chemokine mRNA expression in the antral mucosa, which may be relevant to the increased mucosal damage associated with cagA positive $H$ pylori infection.

(F Clin Pathol 1998;51:765-770)
\end{abstract}

Keywords: Helicobacter pylori; chemokine; gastritis; cagA; neutrophil

Many studies have implicated infection with Helicobacter pylori in the pathogenesis of chronic gastritis. Histologically, the host response to $H$ pylori infection is characterised by infiltration of lymphocytes, macrophages, and neutrophils into the gastric mucosa. ${ }^{1}$ In addition, various inflammatory mediators have been detected in higher concentrations in infected gastric mucosa. Chemokines are a recently described family of inflammatory cytokines that have leucocyte chemotactic and activating properties. ${ }^{2-4}$ The chemokine superfamily has been divided into two major subgroups: the $\mathrm{C}-\mathrm{X}-\mathrm{C}$ and the $\mathrm{C}-\mathrm{C}$ chemokines. These two subfamilies differ in their biological properties. In general, the $\mathrm{C}-\mathrm{X}-\mathrm{C}$ chemokines seem to affect primarily neutrophils, while the $\mathrm{C}-\mathrm{C}$ chemokines have functional action on monocytes and lymphocytes. ${ }^{23}$ These selective chemoattractant activities of chemokines play a major role in regulating leucocyte populations migrating into tissues.

Previous studies have shown that $H$ pylori infection is associated with increased gastric mucosal interleukin-8 (IL-8).$^{5-7}$ H pylori strains expressing the cytotoxin associate gene A (cagA) have been associated with increased gastric mucosal IL-8 in vivo ${ }^{89}$ and with induction of IL-8 in gastric epithelial cell lines in vitro. ${ }^{10-12}$ The cagA gene is part of the cag pathogenicity island (PAI) and is not the direct inducer of IL-8, ${ }^{11}{ }^{12}$ but multiple genes in the cag PAI are essential for induction of epithelial chemokines. ${ }^{13}{ }^{14}$ While there have been many studies on IL-8 in the gastric mucosa, other members of the chemokine family have not been fully investigated. Studies to date have not quantified mRNA expression of chemokines, and the relation to gastric histopathology has not been evaluated. In this study, using semiquantitative reverse transcription polymerase chain reaction (RT-PCR), we have investigated the gastric mRNA expression of three C-X-C chemokines (IL-8, growth related oncogene alpha $(\mathrm{GRO} \alpha)$, epithelial neutrophil activating protein 78 (ENA-78)) and two C-C chemokines (Regulated on Activation Normal T cell Expressed and Secreted (RANTES) and monocyte chemotactic protein-1 (MCP-1)). We have examined the association between chemokine mRNA expression, severity of gastritis, and presence of the cagA positive $H$ pylori infection.

\section{Methods}

PATIENTS

Patients with dyspeptic symptoms scheduled for upper gastrointestinal endoscopy were prospectively enrolled into the study. Patients were excluded if they were over 70 years old, were receiving steroids and non-steroidal antiinflammatory drugs, or had received anti-ulcer agents or antibiotics during the two months before the examination. All subjects provided 
Table 1 Oligonucleotide primers for reverse transcriptase polymerase chain reaction

\begin{tabular}{|c|c|c|c|}
\hline Gene & & Primer & $\begin{array}{l}\text { Expected product } \\
\text { size }\end{array}$ \\
\hline G3PDH & $\begin{array}{l}\text { sense } \\
\text { antisense }\end{array}$ & $\begin{array}{l}\text { GAGTCAACGGATTTGGTCGT } \\
\text { TTCCCGTTCTCAGCCTTGAC }\end{array}$ & 178 \\
\hline IL-8 & $\begin{array}{l}\text { sense } \\
\text { antisense }\end{array}$ & $\begin{array}{l}\text { AAGGAACCATCTCACTG } \\
\text { GATTCTTGGATACCACAGAG }\end{array}$ & 352 \\
\hline $\operatorname{GRO} \alpha$ & $\begin{array}{l}\text { sense } \\
\text { antisense }\end{array}$ & $\begin{array}{l}\text { ATGGCCCGCGCTGCTCTCT } \\
\text { AGCTTTCCGCCCATTCTTG }\end{array}$ & 255 \\
\hline ENA-78 & $\begin{array}{l}\text { sense } \\
\text { antisense }\end{array}$ & $\begin{array}{l}\text { GTGTTGAGAGAGCTGCGTTG } \\
\text { TTTTCCTTGTTTCCACCGCT }\end{array}$ & 215 \\
\hline RANTES & $\begin{array}{l}\text { sense } \\
\text { antisense }\end{array}$ & $\begin{array}{l}\text { ATGAAGGTCTCCGCGGCACGC } \\
\text { CTAGCTCATCTCCAAAGAGTT }\end{array}$ & 276 \\
\hline MCP-1 & $\begin{array}{l}\text { sense } \\
\text { antisense }\end{array}$ & $\begin{array}{l}\text { TCCTGTGCCTGCTGCTCATAGC } \\
\text { TTCTGAACCCACTTCTGCTTGG }\end{array}$ & 235 \\
\hline cagA & $\begin{array}{l}\text { sense } \\
\text { antisense }\end{array}$ & $\begin{array}{l}\text { GATAACGCTGTCGCTTCATACG } \\
\text { CTGCAAAAGATTGTTTGGCAGA }\end{array}$ & 409 \\
\hline ureA & $\begin{array}{l}\text { sense } \\
\text { antisense }\end{array}$ & $\begin{array}{l}\text { GCCAATGGTAAATTAGTT } \\
\text { CTCCTTAATTGTTTTTAC }\end{array}$ & 411 \\
\hline
\end{tabular}

informed consent before their endoscopy. The study was approved by the local clinical research ethics committee.

At endoscopy, biopsy specimens were taken from the antrum and the corpus of the stomach. One biopsy specimen from the antrum and corpus was used for CLO test (Delta West Pty, Australia). Two biopsy specimens from the antrum and the corpus were snap frozen and stored at $-80^{\circ} \mathrm{C}$ before RNA extraction. Two antral and corpus biopsies were taken for histological evaluation. Sections
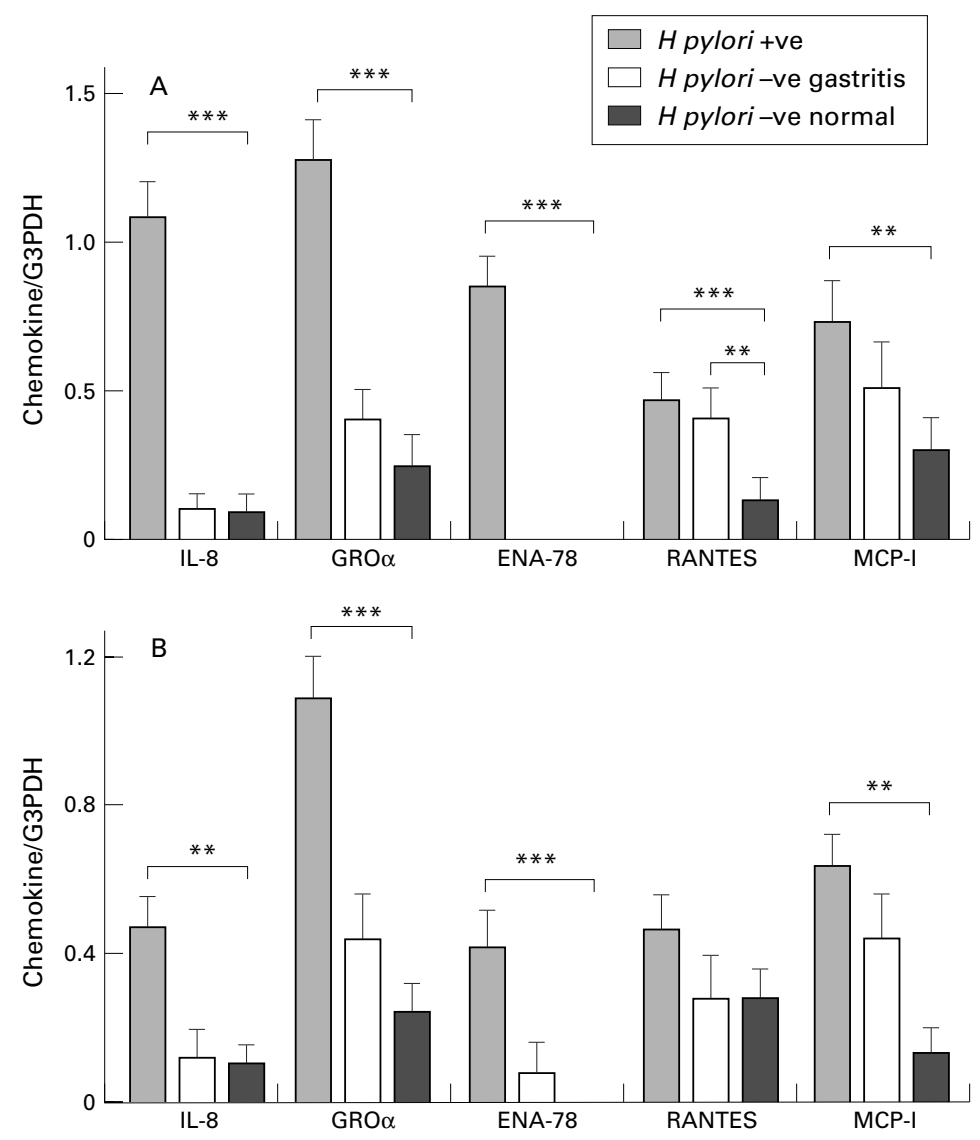

Figure 1 Chemokine $m R N A$ expression in the antral $(A)$ and corpus $(B)$ mucosa in patients with or without $H$ pylori infection. ${ }^{\star \star} p<0.01,{ }^{\star \star \star} p<0.001 v$ control group. of biopsies were examined without knowledge of the experimental results by one histopathologist (MFD). Mononuclear cell infiltration, neutrophil cell infiltration, and $H$ pylori density were graded using a visual analogue scale with units of 0 to 100 for each feature. ${ }^{15}$ The modified Giemsa stain was used for identification of $H$ pylori.

\section{RNA EXTRACTION AND COMPLEMENTARY DNA} SYNTHESIS

Total RNA was extracted from biopsy specimens using Catrimox-14 ${ }^{\mathrm{TM}}$ (Iowa Biotechnology Corporation). ${ }^{16}$ Each RNA sample was suspended in water containing $1 \mathrm{U} / \mu \mathrm{l}$ of RNasin $^{\mathrm{TM}}$ (ribonuclease inhibitor; Promega). Ten microlitres of each RNA solution was used for reverse transcription using Random Primers ${ }^{\mathrm{TM}}$ (random hexamer; Promega). Before reverse transcription, to avoid genomic DNA contamination, RNA samples received deoxyribonuclease treatment using DNase $\mathrm{I}^{\mathrm{TM}}$ (Gibco BRL). The samples were reverse transcribed in a final volume of $20 \mu \mathrm{l}$ solution containing $50 \mathrm{mM}$ Tris- $\mathrm{HCl}, 75 \mathrm{mM} \mathrm{KCl}, 3 \mathrm{mM} \mathrm{MgCl}, 10 \mathrm{mM}$ dithiothreitol, $0.5 \mathrm{mM}$ each dNTPs, $20 \mathrm{U}$ RNasin, $0.5 \mu \mathrm{g}$ Random Primers, and $120 \mathrm{U}$ M-MLV Reverse Transcriptase ${ }^{\mathrm{TM}}$ (Promega). The mixture was incubated at $42^{\circ} \mathrm{C}$ for 60 minutes and heated at $95^{\circ} \mathrm{C}$ for 10 minutes.

PCR AND SEMIQUANTITATION OF PCR PRODUCTS The sequences of primers are shown in table 1 . The chemokine and glyceraldehyde 3-phosphate dehydrogenase (G3PDH) primers were designed to include at least one intron to produce different size or no products if any residual genomic DNA was present. One microlitre of cDNA solution was added to $20 \mu \mathrm{l}$ reaction mixture containing $10 \mathrm{mM}$ Tris- $\mathrm{HCl}$, $50 \mathrm{mM} \mathrm{KCl}, 4.5 \mathrm{mM} \mathrm{MgCl}_{2}$ (ureA) or $3.0 \mathrm{mM}$ $\mathrm{MgCl}_{2}$ (MCP-1) or $1.5 \mathrm{mM} \mathrm{MgCl}_{2}$ (other genes), $200 \mu \mathrm{M}$ each dNTPs, $20 \mathrm{pmol}$ of each primer, and $1.0 \mathrm{U}$ of Taq DNA polymerase (Promega). After five minutes denaturing at $95^{\circ} \mathrm{C}, 30$ cycles (chemokine and $\mathrm{G} 3 \mathrm{PDH}$ ) or 40 cycles (ureA and cagA) PCR were performed.

PCR products were electrophoresed in 2\% agarose gel. Eight microlitre aliquots of each chemokine PCR product were electrophoresed with $8 \mu \mathrm{l}$ aliquots of G3PDH product in the same well. Quantities of chemokine PCR products were compared with G3PDH products in corresponding mucosa by densitometry. ${ }^{17}$ In brief, the gel image was electronically digitised to determine the peak height and the area measurements of each band, and the ratios of chemokines to G3PDH were calculated using a UVP gel documentation system and GelBase software (GDS 5000; Ultra Violet Products).

Products of ureA and cagA were also examined in $2 \%$ agarose gel. The sensitivities of ureA and cagA PCR were 50 and 25 colony forming units respectively.

STATISTICAL ANALYSIS

All results of chemokine/G3PDH ratios were expressed as mean (SEM) and were compared 

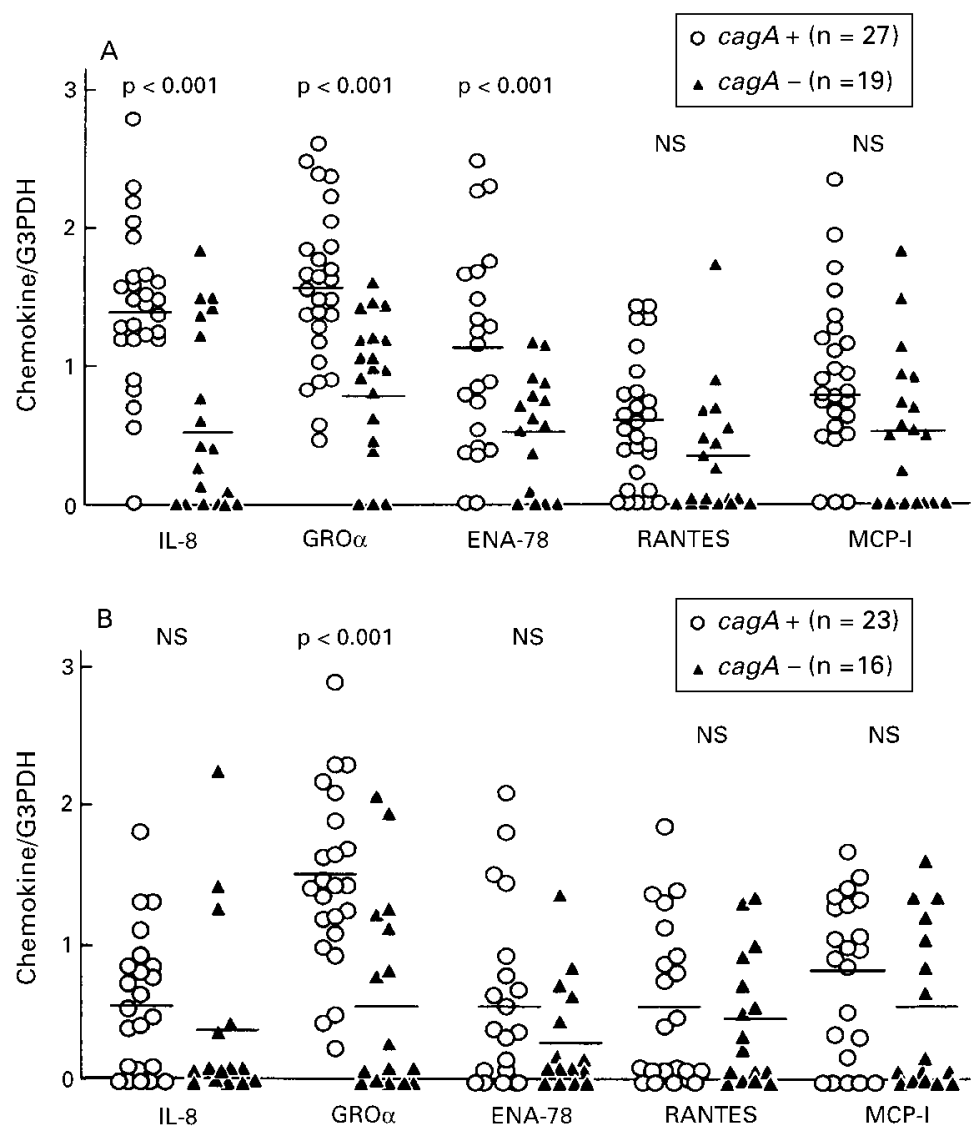

Figure 2 Chemokine $m R N A$ expression in cagA positive and cagA negative antral $(A)$ and corpus (B) mucosa in patients with $H$ pylori infection.

Table 2 Mean chemokine/G3PDH $m R N A$ expression ratio in the antral mucosa in $H$ pylori negative patients

\begin{tabular}{lrlllll}
\hline \multicolumn{7}{c}{ Gene } \\
\cline { 3 - 7 } & \multicolumn{1}{l}{$n$} & IL-8 & GROa & ENA-78 & RANTES & MCP-1 \\
\hline Chronic gastritis & 10 & 0.043 & $0.577^{\star}$ & 0 & $0.496^{\star}$ & 0.465 \\
Reactive gastritis & 7 & 0.247 & 0.351 & 0 & $0.597^{\star \star}$ & 0.816 \\
Normal & 20 & 0.103 & 0.250 & 0 & 0.135 & 0.299 \\
\hline
\end{tabular}

${ }^{\star} \mathrm{p}<0.05,{ }^{\star \star} \mathrm{p}<0.01 v$ normal.

by the Student $t$ test. Determinations of Pearson's correlation coefficient were also made to examine the relation between the chemokine/G3PDH ratios and the visual analogue scales of gastric histopathology. H pylori density was expressed as mean (SEM) and the differences were compared by the Student $t$ test. A probability $(\mathrm{p})$ value less than 0.05 was considered statistically significant.

Table 3 Correlations between chemokine mRNA expression and mononuclear cell (MNC) infiltration in gastric mucosa with $H$ pylori infection

\begin{tabular}{|c|c|c|c|c|c|}
\hline \multirow{2}{*}{$\begin{array}{l}\text { MNC } \\
\text { infiltration }\end{array}$} & \multicolumn{5}{|l|}{ Gene } \\
\hline & $I L-8$ & GROa & $E N A-78$ & RANTES & $M C P-1$ \\
\hline \multicolumn{6}{|l|}{ Antrum } \\
\hline H pylori + & $0.389^{\star \star}$ & $0.440^{\star \star}$ & $0.459^{\star \star}$ & 0.203 & $0.402^{\star \star}$ \\
\hline $\operatorname{cag} \mathrm{A}+$ & $0.411^{\star}$ & $0.437^{\star}$ & $0.416^{\star}$ & 0.231 & $0.391^{\star}$ \\
\hline $\begin{array}{l}\text { cagA- } \\
\text { Corpus }\end{array}$ & 0.365 & $0.459^{\star}$ & $0.650^{\star \star}$ & 0.101 & 0.377 \\
\hline H pylori + & $0.423^{\star \star}$ & $0.662^{\star \star \star}$ & $0.712^{\star \star \star}$ & 0.126 & 0.171 \\
\hline cagA + & $0.428^{\star}$ & $0.667^{\star \star \star}$ & $0.804^{\star \star \star}$ & 0.017 & 0.066 \\
\hline cagA- & 0.402 & $0.643^{\star \star}$ & 0.354 & 0.378 & 0.266 \\
\hline
\end{tabular}

$r$ Values determined by Pearson correlation coefficient: ${ }^{\star} \mathrm{p}<0.05,{ }^{\star \star} \mathrm{p}<0.01,{ }^{\star \star \star} \mathrm{p}<0.001$.

\section{Results}

Eighty three patients were included in the study. Endoscopic diagnoses were duodenal ulcer (4), duodenitis (3), gastric ulcer (3), gastric polyp (1), and reflux oesophagitis (5). Antral biopsies were obtained from all patients. The patients were considered $H$ pylori positive if at least two of CLO test, histology, and ureA RT-PCR were positive. On this basis 46 patients were defined as $H$ pylori positive. Twenty seven of the $46 H$ pylori positive patients were cagA positive. In $37 \mathrm{H}$ pylori negative patients, 20 patients had histologically normal mucosa and were defined as the normal control group. In the other $17 \mathrm{H}$ pylori negative patients, histologically 10 had chronic gastritis and seven were diagnosed as having reactive gastritis. These patients were classified as the $H$ pylori negative gastritis group. There was no difference between groups with respect to age.

Corpus biopsies were obtained for RNA analysis from 63 patients. Thirty nine were $H$ pylori positive, and 23 were cagA positive. In the $24 \mathrm{H}$ pylori negative patients, histologically 16 patients were classified as the normal control group, three with chronic gastritis (one autoimmune type) and five with reactive gastritis. One patient had $H$ pylori negative reactive gastritis in the antral mucosa and cagA positive gastritis in the corpus mucosa.

In cagA positive patients, the mean bacterial density assessed by visual analogue scale was 55.8 (SEM 5.7) units in the antrum and 36.5 (6.2) in the corpus, and the difference was significant $(\mathrm{p}<0.05)$. In cagA negative patients, there was no significant difference in the mean bacterial density score in the antrum 39.9 (7.1) and in the corpus 22.5 (5.6). Bacterial density was not significantly different between cagA positive and cagA negative patients in either the antrum or the corpus.

\section{CHEMOKINE MRNA EXPRESSION AND H PYLORI}

STATUS

Chemokine mRNA expression was increased in $H$ pylori positive mucosa compared with the normal control group (fig 1). In the antral mucosa, mRNA expression of all chemokines was significantly greater in $H$ pylori positive patients than in control patients (fig $1 \mathrm{~A}$ ). In the corpus mucosa, expression of IL-8, GRO $\alpha$, ENA-78, and MCP-1 was also greater in $H$ pylori positive patients (fig 1B). In $H$ pylori negative patients with gastritis, only RANTES mRNA expression was significantly greater in the antrum than the $H$ pylori negative controls (fig 1A).

In the antrum, expression of IL-8, GRO $\alpha$, and ENA-78 mRNA was significantly greater in cagA positive mucosa than in cagA negative mucosa (fig 2A). Although RANTES and MCP-1 mRNA expression was increased in cagA positive mucosa compared with cagA negative mucosa, the differences were not significant (fig 2A). In the corpus mucosa, significant increases in chemokine mRNA expression in cagA positive infection was observed only for GRO $\alpha$ (fig 2B).

In 22 cagA positive patients and 16 cagA negative patients, chemokine to G3PDH ratios 


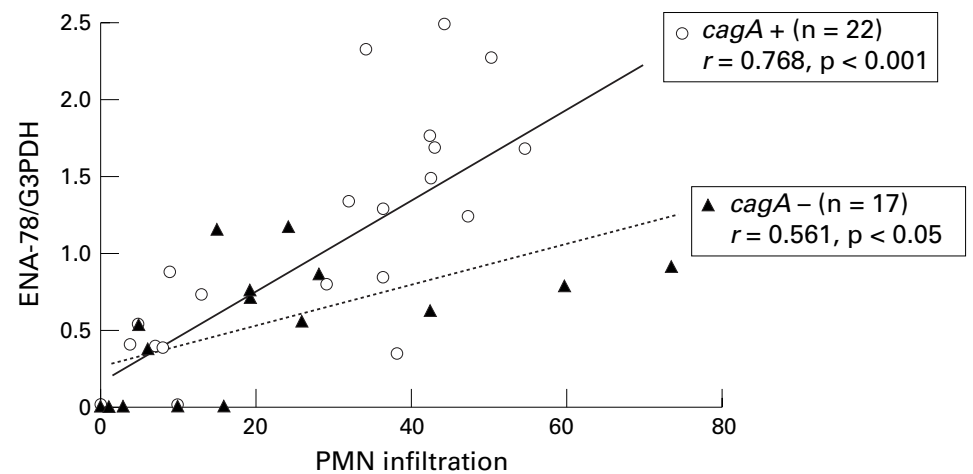

Figure 3 Correlations between neutrophil activity and ENA78 $m$ RNA expression in the antral mucosa in patients with $H$ pylori infection. A solid line and a broken line represent regression lines in cag $A$ positive and cag $A$ negative mucosa respectively.

Table 4 Correlations between chemokine RNA expression and polymorphonuclear neutrophil (PMN) infiltration in gastric mucosa with H pylori infection

\begin{tabular}{|c|c|c|c|c|c|}
\hline \multirow{2}{*}{$\begin{array}{l}\text { PMN } \\
\text { infiltration }\end{array}$} & \multicolumn{5}{|l|}{ Gene } \\
\hline & $I L-8$ & $G R O a$ & $E N A-78$ & RANTES & $M C P-1$ \\
\hline \multicolumn{6}{|l|}{ Antrum } \\
\hline H pylori + & $0.681^{\star \star \star}$ & $0.588^{\star \star \star \star}$ & $0.656^{\star \star \star}$ & 0.313 & 0.190 \\
\hline $\operatorname{cagA}+$ & $0.691^{\star \star \star}$ & $0.619^{\star \star \star}$ & $0.768^{\star \star \star}$ & 0.256 & 0.004 \\
\hline cagA - & 0.365 & $0.544^{\star}$ & $0.561^{\star}$ & 0.309 & 0.341 \\
\hline \multicolumn{6}{|l|}{ Corpus } \\
\hline H pylori + & $0.537^{\star \star \star}$ & $0.721^{\star \star \star}$ & $0.828^{\star \star \star}$ & 0.044 & 0.159 \\
\hline cagA + & $0.517^{\star}$ & $0.710^{\star \star \star}$ & $0.863^{\star \star \star}$ & 0.036 & 0.133 \\
\hline cagA - & 0.442 & $0.764^{\star \star \star}$ & $0.611^{\star}$ & 0.244 & 0.081 \\
\hline
\end{tabular}

$r$ Values determined by Pearson correlation coefficient: ${ }^{\star} \mathrm{p}<0.05,{ }^{\star \star \star} \mathrm{p}<0.001$.

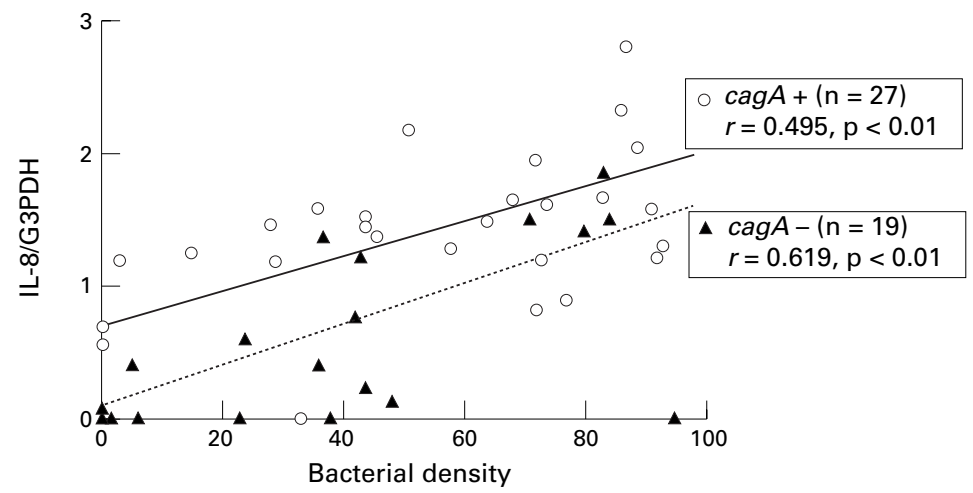

Figure 4 Correlations between bacterial density and IL-8 $m R N A$ expression in the antral mucosa in patients with $H$ pylori infection. A solid line and a broken line represent regression lines in cag $A$ positive and cag $A$ negative mucosa respectively.

Table 5 Correlation between chemokine $m R N A$ expression and bacterial density in gastric mucosa with $H$ pylori infection

\begin{tabular}{llllll}
\hline \multirow{2}{*}{ Bacterial density } & \multicolumn{2}{l}{ Gene } & & & \\
\cline { 2 - 6 } & $I L-8$ & $G R O a$ & ENA-78 & RANTES & MCP-1 \\
\hline Antrum & & & & & \\
H pylori + & $0.585^{\star \star \star}$ & $0.585^{\star \star \star}$ & $0.534^{\star \star \star}$ & $0.303^{\star}$ & $0.346^{\star}$ \\
cagA + & $0.495^{\star \star}$ & $0.701^{\star \star \star}$ & $0.475^{\star}$ & 0.152 & 0.270 \\
cagA - & $0.619^{\star \star}$ & $0.538^{\star}$ & $0.664^{\star \star}$ & 0.399 & 0.331 \\
Corpus & $0.377^{\star}$ & $0.425^{\star \star}$ & $0.458^{\star \star}$ & 0.183 & 0.148 \\
H pylori + & 0.347 & 0.288 & $0.441^{\star}$ & 0.064 & 0.091 \\
cagA + & 0.391 & $0.638^{\star \star}$ & 0.379 & 0.452 & 0.146 \\
cagA - & & & &
\end{tabular}

$r$ Values determined by Pearson correlation coefficient: ${ }^{\star} \mathrm{p}<0.05,{ }^{\star \star} \mathrm{p}<0.01,{ }^{\star \star \star} \mathrm{p}<0.001$.

were available both for the antral and the corpus. In cagA positive patients, IL-8 and ENA-78 mRNA expression was significantly greater in the antral mucosa than in the corpus mucosa while there was no significant difference in cagA negative patients. IL-8 to G3PDH ratios for the antrum and corpus were respectively $1.45(0.12)$ and $0.52(0.11)$, while
ENA-78 to G3PDH ratios were $1.12(0.18)$ (antrum) and $0.60(0.16)$ (corpus). There was no significant difference in expression of GRO $\alpha$, RANTES, and MCP-1 mRNA between the antral and corpus mucosa.

\section{CHEMOKINE MRNA EXPRESSION IN H PYLORI} NEGATIVE GASTRITIS

The $H$ pylori negative gastritis group consisted of patients with both chronic gastritis and reactive gastritis. Subgroup analysis of chemokine mRNA expression in the antral mucosa is shown in table 2. GRO $\alpha$ and RANTES mRNA expression was significantly greater in patients with $H$ pylori negative chronic gastritis than in the control group. In patients with reactive gastritis patients RANTES mRNA expression was also significantly greater than in the control group.

CORRELATIONS BETWEEN CHEMOKINE MRNA EXPRESSION AND GRADE OF H PYLORI GASTRITIS Significant correlations were found between mononuclear cell infiltration and chemokine mRNA expression (table 3 ). In cagA positive mucosa, mononuclear cell infiltration was correlated with mRNA expression of IL-8, GRO $\alpha$, ENA-78, and MCP-1 in the antrum, and with IL-8, GRO $\alpha$, and ENA-78 in the corpus. In cagA negative mucosa, significant correlations between mononuclear cell infiltrate and chemokine mRNA expression were found for GRO $\alpha$ and ENA-78 in the antrum and GRO $\alpha$ in the corpus.

Neutrophil infiltration was significantly correlated with C-X-C chemokine mRNA expression (fig 3, table 4). In cagA positive mucosa, neutrophil infiltration correlated with $\mathrm{mRNA}$ expression of IL-8, GRO $\alpha$, and ENA-78 in both the antrum and corpus. In cagA negative mucosa, correlations were significant for GRO $\alpha$ and ENA-78 but there was no significant correlation between neutrophil infiltration and IL-8 mRNA expression. No significant correlation was observed between neutrophil infiltration and C-C chemokines.

Bacterial density was also correlated with C-X-C chemokine mRNA expression (fig 4, table 5). In cagA positive mucosa, bacterial density correlated with $\mathrm{mRNA}$ expression of IL-8, GRO $\alpha$, and ENA-78 in the antrum, and only with ENA-78 in the corpus. In cagA negative mucosa, correlations were significant with IL-8, GRO $\alpha$, and ENA-78 in the antrum, and only with GRO $\alpha$ in the corpus. There was no significant correlation between bacterial density of cagA negative or cagA positive infection and $\mathrm{C}-\mathrm{C}$ chemokine mRNA expression.

\section{Discussion}

There has been recent interest in the role of chemokines in gastric mucosa with $H$ pylori infection. In this study, we investigated the mRNA expression of several chemokines in the gastric mucosa using semiquantitative RTPCR. Our previous in vitro studies with gastric epithelial cells have shown a good correlation between IL-8:G3PDH mRNA using this semiquantitative RT-PCR approach and secreted IL-8 product. $^{10}$ The use of visual analogue 
scales enabled us to evaluate the correlations between chemokine mRNA expression and histological grade of gastritis. The results suggest that $\mathrm{C}-\mathrm{X}-\mathrm{C}$ chemokines may play a primary role in $\mathrm{H}$ pylori gastritis.

Both C-X-C and C-C chemokines have been implicated in many chronic inflammatory conditions. ${ }^{18-24}$ Gastrointestinal epithelial cells have recently been shown to express and secrete several chemokines. ${ }^{10-1225}$ Chemokine expression is induced in both human colonic epithelial cells and mononuclear cells in response to bacterial infection. ${ }^{26}{ }^{27}$ Increased colonic C-X-C and C-C chemokines are found in inflammatory bowel disease. ${ }^{28} 29$ Although early studies showed increased IL-8 production in gastric mucosa infected with $\mathrm{H}$ pylori, ${ }^{56}$ the involvement of other chemokines in gastritis has not been investigated in detail. Our results show that patients infected with $H$ pylori have significantly greater $\mathrm{mRNA}$ expression of both C-X-C and C-C chemokines in the gastric mucosa than patients without $H$ pylori infection.

Many studies have focused on strain diversity of $H$ pylori and they have shown that infection with cagA positive strains is closely associated with gastroduodenal diseases. ${ }^{30-37}$ Infection with cagA positive strains is associated with increased gastric IL-8 mRNA expression $^{8}$ and IL-8 protein in vivo. ${ }^{9}$ In vitro studies have also shown that the ability of $H$ pylori to induce chemokines in gastric epithelial cell lines varies and the response is restricted to strains with the cagA phenotype. ${ }^{10-14} 38$ Our present study shows that patients infected with cagA positive strains have greater gastric C-X-C chemokine mRNA expression than those infected with cagA negative $H$ pylori. Atherton et al showed that cagA positive strains colonise at a greater density than cagA negative strains. $^{39}$ However, others have found no significant difference in colony forming units between cagA positive and cagA negative patients. ${ }^{40}$ In the present study, although the bacterial densities were higher in cagA positive patients, the difference was not significant. Thus cagA positive strains appear to induce greater $\mathrm{C}-\mathrm{X}-\mathrm{C}$ chemokine mRNA expression in the gastric mucosa. This is apparent particularly at low bacterial density (fig 4).

Interestingly, expression of IL-8 and ENA-78 mRNA was greater in the antrum than in the corpus only in patients with cagA positive infection. Variations in bacterial density could be one explanation for differences in chemokine mRNA expression between antrum and corpus. In cagA positive patients, bacterial density was significantly higher in the antrum than in the corpus $(\mathrm{p}<0.05)$. By contrast, no difference was seen in cagA negative patients. High acid in the corpus mucosa may also affect bacterial-epithelial interactions by influencing transcription of bacterial genes in the cag PAI and other related virulence genes. ${ }^{41}$ Differences in chemokine induction could explain why inflammation in cagA seropositive patients is significantly increased relative to cagA seronegatives only in the antral mucosa. ${ }^{42}{ }^{43}$ Furthermore, Bayerdorffer et al showed $H$ pylori infec- tion of similar density caused a higher grade of gastritis in the antrum than in the corpus. ${ }^{44}$ Their findings and our results suggest that increased chemokine stimulation may contribute to enhanced immunological responses to $H$ pylori in the antrum rather than in the corpus.

In this study, the grade of gastritis was evaluated using visual analogue scales, which allows more precise examination of the correlations between histology and chemokine mRNA expression. Previous studies have shown increased IL-8 protein and mRNA expression in gastric mucosa is associated with greater mononuclear cell infiltration or neutrophil infiltration, as classified by the Sydney system. $^{68945}$ The correlations between IL-8 mRNA expression and mononuclear cell infiltration and neutrophil activity were significant in $H$ pylori positive gastric mucosa. We also examined these correlations in cagA positive and cagA negative infection and showed significant correlations for IL-8 and neutrophil infiltration only in patients infected with cagA positive strains. The mRNA expression of other C-X-C chemokines, GRO $\alpha$, and ENA-78 was also positively correlated with both mononuclear cell and neutrophil infiltration in $H$ pylori positive gastric mucosa. As expected, correlations of $\mathrm{C}-\mathrm{X}-\mathrm{C}$ chemokine mRNA expression were stronger with neutrophil infiltration than with mononuclear cell infiltration. C-X-C chemokines are likely to play an important role in gastric mucosal neutrophil migration and account for the more active gastritis associated with cagA positive infection. The correlations between C-C chemokine mRNA expression and mononuclear cell and neutrophil infiltration were quite different. Significant correlation was seen only between MCP-1 mRNA expression and mononuclear cell infiltration. Though $\mathrm{C}-\mathrm{C}$ chemokine mRNA expression was increased in $\mathrm{H}$ pylori positive gastric mucosa, its importance might not be comparable to that of the C-X-C chemokines. Additionally, in patients with $H$ pylori negative gastritis who had some mononuclear cell infiltration but no neutrophil infiltration, the mRNA expression of the $\mathrm{C}-\mathrm{C}$ chemokine RANTES is increased.

We also examined the correlations between bacterial density and chemokine mRNA expression. Bacterial density was correlated with mRNA expression of all chemokines in $\mathrm{H}$ pylori positive antral mucosa. However, these correlations were generally stronger in cagA negative patients than in cagA positive patients. Greater chemokine mRNA expression in cagA positive infection at low bacterial densities will be a result of induction of epithelial chemokines by cag PAI genes. In contrast, induction of chemokines in cagA negative infection will depend on mucosal mononuclear cell activation and relate more strongly to bacterial density. Recent studies have shown that IL- 8 protein content of antral biopsies is related to the density of $H$ pylori infection. ${ }^{45}$

In conclusion, chemokines have a role in $H$ pylori positive gastritis. Enhanced C-X-C chemokine responses are induced by cagA 
positive $H$ pylori strains resulting in histologically more intense gastritis. Infection with cagA positive strains is associated clinically with more severe outcomes, and variability in host chemokine responses may thus contribute to the clinical outcome of $H$ pylori infection.

We thank Dr I Lindley of Novartis for providing the RANTES MCP-1, and GRO $\alpha$ primers, and Dr S Farmery for helpful discussion. This study was undertaken with financial support from the European Commission (contract number IC18CT950024) and the Yorkshire Cancer Research Campaign. The study was
presented in part at the 97 th annual meeting of AGA in Washington DC in May 1997 and at the Xth International Workshop on Gastroduodenal Pathology and Helicobacter pylori, in Lisbon, Portugal, in September 1997, and published in abstract form in Gastroenterology (1997;112:A1091) and Gut (1997;41(suppl 1):A61).

1 Price AB. The Sydney system: histological division. $\mathcal{F}$ Gastroenterol Hepatol 1991:6:209-22.

2 Miller MD, Krangel MS. Biology and biochemistry of the chemokines: a family of chemotactic and inflammatory cytokines. CRC Crit Rev Immunol 1992;12:17-46.

3 Baggiolini M. Chemotactic and inflammatory cytokinesCXC and CC proteins. In: Lindley IJD, ed. The chemokines. CXC and CC proteins. In: Lindley IJD,
New York: Plenum Press, 1993: 1-10. $4 \begin{gathered}\text { Baggiolini M, Dewald B, Moser B. Interleukin-8 and related } \\ \text { chemotactic cytokines - CXC and CC chemokines. Adv }\end{gathered}$ chemotactic cytokines - CXC
Immunol Rev 1994;55:97-179.

5 Crabtree JE, Wyatt JI, Trejdosiewicz LK, et al. Interleukin-8 expression in Helicobacter pylori, normal and neoplastic gastroduodenal mucosa. F Clin Pathol 1994;47:61-6.

6 Crabtree JE, Peichl P, Wyatt JI, et al. Gastric IL-8 and IL-8 IgA autoantibodies in Helicobacter pylori infection. Scand f Immunol 1993;37:65-70

7 Yamaoka Y, Kita M, Kodama T, et al. Expression of cytokine mRNA in gastric mucosa with Helicobacter pylori infection. Scand 7 Gastroenterol 1995;30:1153-9.

8 Yamaoka Y, Kita M, Kodama T, et al. Helicobacter pylori cagA gene and expression of cytokine messenger RNA in gastric mucosa. Gastroenterology 1996;110:1744-52.

9 Peek RM, Miller GG, Tham KT, et al. Heightened inflammatory response and cytokine expression in vivo to cagA+ Helicobacter pylori strains. Lab Invest 1995;73:760-70.

10 Crabtree JE, Farmery SM, Lindley IJD, et al. CagA cytotoxic strains of Helicobacter pylori and interleukin-8 in gastric epithelial cells. F Clin Pathol 1994;47:945-50.

11 Crabtree JE, Covacci A, Farmery SM, et al. Helicobacter pylori and induced interleukin-8 expression in gastric epithelial cells is associated with cagA positive phenotype. $\mathcal{F}$ Clin Pathol 1995;48:967-9.

12 Sharma SA, Tummuru MKR, Miller GG, et al. Interleukin-8 response of gastric epithelial cell lines to Helicobacter pylori stimulation in vitro. Infect Immun 1995; 63:1681-7.

13 Censini S, Lange C, Xiang Z, et al. Cag A pathogenicity island of Helicobacter pylori, encodes type I-specific and disease-associated virulence factors. Proc Natl Acad Sci USA 1996;93:14648-53.

14 Crabtree JE, Kersulyte D, Hernandez V, et al. Helicobacter pylori induction of IL-8 synthesis in gastric epithelial cells depends on genes throughout the cag pathogenicity island [abstr]. Gastroenterology 1997;112:A95.

15 Dixon MF, Genta RM, Yardley JH, et al. Classification and grading of gastritis. Am 7 Surg Pathol 1996;20:1161-81.

16 Mrading of gastritis. Am F Surg Pathol 1996;20:1161-81. blood-the dawn of RNA-based diagnosis? Nature 1993; 362:186-8.

17 Farmery SM, Crabtree JE. Host response to $\mathrm{H}$ pylori molecular analysis of cytokine gene expression. In Clayton CL, Mobley HL, eds. Helicobacter pylori protocol. New Jersey: Humana Press, 1997:225-34.

18 Richmond A, Thomas HG. Melanoma growth stimulatory activity: isolation from human melanoma tumors and characterization of tissue distribution. F Cell Biochem 1988;36: 185-98.

19 Becker S, Quay J, Koren HS, et al. Constitutive and stimulated MCP-1, GRO $\alpha, \beta$ and $\gamma$ expression in human airway epithelium and bronchoalveolar macrophages. Am $\mathcal{F}$ Physiol 1994;266:L278-86.

20 Walz A, Burgener R, Car B, et al. Structure and neutrophilactivating properties of a novel inflammatory peptide
(ENA-78) with homology to interleukin-8. F Exp Med 1991;174:1355.

21 Koch AE, Kunkel SL, Harlow LA, et al. Epithelial neutrophil activating peptide-78: a novel chemotactic cytokine for neutrophils in arthritis. $\mathcal{F}$ Clin Invest 1994;94:101218.
22 Schall TJ, Jongstra J, Dyer BJ, et al. A human T cell-specific molecule is a member of a new gene family. F Immunol 988;141:1018-25.

23 Berkman N, Robichaud A, Krishman VL, et al. Expression of RANTES in human airway epithelial cells: effect of corticosteroids and interleukin-4, $-10,-13$. Immunology 1996;87:599-603.

24 Yoshimura T, Robinson EA, Tanaka S, et al. Purification and amino acid analysis of two human monocyte chemoattractants produced by phytohemagglutinin-stimulated human blood mononuclear leukocytes. F Immunol 1989;142:195662.

25 Kagnoff MF, Eckmann L. Epithelial cells as sensors of microbial infection $\mathcal{f}$ Clin Invest 1997;100:6-10.

26 Jung HC, Eckmann L, Yang SK, et al. A distinct array of proinflammatory cytokines is expressed in human colon epithelial cells in response to bacterial invasion. $f$ Clin Invest 1995;95:55-65.

27 Jiang Y, Russell TR, Graves DT, et al. Monocyte chemoattractant protein 1 and interleukin- 8 production in mononuclear cells stimulated by oral micro-organisms. Infect Immun 1996;64:4450-5.

28 Reinecker HC, Loh EY, Ringler DJ, et al. Monocytechemoattractant protein 1 gene expression in intestinal epithelial cells and inflammatory bowel mucosa. Gastroenterology 1997;108:40-50.

29 Isaacs KL, Sartor RB, Haskill S. Cytokine messenger RNA profiles in inflammatory bowel disease mucosa detected by polymerase chain reaction amplification. Gastroenterology 1992;103:1587-95.

30 Crabtree JE, Taylor JD, Wyatt JI, et al. Mucosal IgA recognition of Helicobacter pylori $120 \mathrm{kDa}$ protein, peptic ulceration, and gastric pathology. Lancet 1991;338:332-5.

31 Weel JFL, van der Hulst RWM, Gerrits Y, et al. The interreationship between cytotoxin-associated gene A, vacuolating cytotoxin, and Helicobacter pylori-related diseases. $\mathcal{f}$ Infect Dis 1996;173:1171-5.

32 Beales ILP, Crabtree JE, Scunes D, et al. Antibodies to CagA protein are associated with gastric atrophy in Helicobacter pylori infection. Eur f Gastroenterol Hepatol 1996;8: 645-9.

33 Kuipers EJ, Pérez-Pérez GI, Meuwissen SGM, et al. Helicobacter pylori and atrophic gastritis: importance of the cagA status. F Natl Cancer Inst 1995;87:1777-80.

34 van der Hulst RWM, van der Ende A, Dekker FW, et al. Effect of Helicobacter pylori eradication on gastritis in relation to cagA: a prospective 1-year follow-up study. Gastroenterology 1997;113:25-30.

35 Crabtree JE, Wyatt JI, Sobala GM, et al. Systemic and mucosal humoral responses to Helicobacter pylori in gastric cancer. Gut 1993;34:1339-43.

36 Blaser MJ, Pérez-Pérez GI, Kleanthous H, et al. Infection of strains possessing cagA is associated with an increased risk of developing adenocarcinoma of the stomach. Cancer Res 1995;55:2111-15.

37 Parsonnet J, Friedman GD, Orentreich N, et al. Risk for gastric cancer in people with CagA positive or CagA negative Helicobacter pylori infection. Gut 1997;40:297-301.

38 Crabtree JE, Farmery SM. Helicobacter pylori and gastric mucosal cytokines: evidence that CagA-positive strains are more virulent. Lab Invest 1995;73:742-5.

39 Atherton JC, Tham KT, Peek RM, et al. Density of Helicobacter pylori infection in vivo as assessed by quantitative culture and histology. F Infect Dis 1996;174:552-6.

40 Husson MO, Gottrand F, Vachee A, et al. Importance in diagnosis of gastritis of detection by PCR of the cagA gene in Helicobacter pylori strains isolated from children. 7 Clin Microbiol 1995;33:3300-3.

41 Karita M, Tummuru MKR, Wirth HP, et al. Effect of growth phase and acid shock on Helicobacter pylori cagA expression. Infect Immun 1996;64:4501-7.

42 Graham DY, Genta RM, Graham DP, et al. Serum CagA antibodies in asymptomatic subjects and patients with peptic ulcer: lack of correlation of IgG antibody in patients with peptic ulcer or asymptomatic Helicobacter pylori gastritis. F Clin Pathol 1996;49:829-32.

43 Crabtree JE, Wyatt JI, Perry S, et al. CagA seropositive Helicobacter pylori infected non-ulcer patients have increased frequency of intestinal metaplasia [abstr]. Gastroenterology 1996;112:A85.

44 Bayerdorffer E, Lehn N, Hatz R, et al. Difference in expression of Helicobacter pylori gastritis in antrum and body. Gastroenterology 1992;102:1575-82.

45 Yamaoka Y, Kita M, Kodama T, et al. Induction of various cytokines and development of severe mucosal inflammation by cagA gene positive Helicobacter pylori strains. Gut 1997;41:442-51. 